\title{
ON THE MORPHOSYNTAX OF INDIGENOUS LANGUAGES OF THE AMERICAS ${ }^{1}$
}

\author{
FERNANDO ZÚÑIGA \\ UNIVERSITY OF BERN
}

\begin{abstract}
Boas (1917) mentioned several phenomena found in the morphosyntax of Amerindian languages (including nominal incorporation and lexical affixation) that posed challenges to accepted views of synchronic and typological issues raised by genealogical relatedness and areal convergence on the continent, morpheme classes like roots, stems, and affixes in languages in general, and whether the fundamental unit of human speech is the word or the sentence. A century later, and despite the increased amount of data available and a substantial amount of theorizing on morphosyntactic issues, these challenges have proved considerably recalcitrant. Framed in terms of morpheme types, word domains, and word classes, this article surveys the progress since Boas's introductory paper and examines open questions in the study of the morphosyntax of indigenous languages of the Americas.

[KEYWORDS: indigenous American languages, morphology, wordhood, lexical affixes]
\end{abstract}

1. Introduction. Boas (1917) considered the study of the morphology and the syntax of indigenous languages of the Americas a challenging enterprise on several grounds. First, he identified several phenomena as important (nominal incorporation, lexical affixation, and the existence of classificatory traits, among others) but mentioned that their distribution and the latter's consequences for classificatory purposes were not yet well understood, particularly because the methods for disentangling inherited commonalities from contact-induced similarities were still in their infancy. Second, he regarded traditional notions like root, stem, and affix, as well as their role both in the description of individual languages and in a general theory of grammar, as potentially challenged by some phenomena found in several linguistic groups of North America. Lastly, a refined but still tentative answer to whether the word or the sentence is the fundamental unit of human speech was, in Boas's mind, a distinctively indigenous American contribution to our understanding of how natural languages work.

A hundred years later, numerous languages of North, Central, and South America are significantly better known; non-negligible progress has been made, especially during the past three or four decades, in understanding contact-induced phenomena; and a vast volume of literature on morphology

${ }^{1}$ I am greatly indebted to an anonymous $I J A L$ reviewer for valuable comments on a previous version of this article. The usual disclaimers apply.

[IJAL, vol. 83, no. 1, January 2017, pp. 111-39]

(C) 2017 by The University of Chicago. All rights reserved.

0020-7071/2017/8301-0004\$10.00 
and syntax has developed during the second half of the century. The challenges identified by Boas, however, have turned out to be recalcitrant. Contact appears to have been pervasive in certain regions and for some periods, but the current lacunae regarding the linguistic prehistory of the continent are so considerable that an adequate reconstruction of genealogical and areal dynamics of change must still be regarded as a largely fragmentary work in progress. Not only the usefulness of traditional morphological modeling but also the assumption of an unproblematic division of labor between morphology and syntax have been recently called into question by both theoretical and typological studies, and analyses of indigenous languages of the Americas have played an important role in the critique of accepted opinions on how best to depict and understand grammatical structure. It seems that the familiar progression "morpheme $>$ word $>$ clause/sentence" is still in need of a refinement informed, at least in part, by Boas's caveats: indigenous languages do suggest that morpheme types are less clear-cut than ordinarily assumed, and that words are more elusive than customarily thought.

This paper surveys the progress and the open questions in the study of the morphosyntax of Native American languages since Boas (1917). Section 2 addresses issues raised by the conceptualization of different kinds of morphemes. Section 3 deals with selected problems encountered in the study of words. Some conclusions are given in $\mathbf{4}$.

2. Morpheme types. The morphological and syntactic processes mentioned by Boas are familiar to present-day scholars. He briefly noted that "nominal cases are present in some languages, absent in others" (Boas 1917:4) but listed a series of other structural phenomena as related to either a common origin or to an area. He identified the fact that "the incorporation of the nominal object, which in former times was considered one of the most characteristic features of American languages, is confined to certain areas, while it is foreign to others" (Boas 1917:4). Regarding lexical affixation, he noted that "[t]he tendency to qualify generalized verbal terms by means of elements which express instrumentality is characteristic of some areas. The occurrence of various specific elements that define locality of an action, ... or other special nominal concepts, is characteristic of other regions" (Boas 1917:4).

Some classificatory traits were of interest to Boas as well; he noted that "[c]lassification of actions or nouns according to the forms of the actor or of the object also belong to several groups of languages" (Boas 1917:4). Lastly, he mentioned several morphological processes as having an interesting distribution: "we find present in some regions, absent in others, processes like that of reduplication or of vocalic or consonantic modification of stems" (Boas 1917:4). 
Lexical affixation and, particularly, nominal incorporation received considerable attention toward the end of the twentieth century. With respect to the former, Mithun (1999:48) says that "affixes with root-like meanings" occur in Salishan, Wakashan, Chimakuan, Tsimshianic, and Eskimo-Aleutian. Lexical affixation has been reported for several Mesoamerican and South American languages (often labeled "incorporation of adverbs"; see Levy 1999 for an in-depth study of classificatory incorporation in Totonacan).

With respect to nominal incorporation, Mithun (1999:44) lists the following (northern) genealogical units that show this phenomenon: Iroquoian, Caddoan, Siouan, Kiowa-Tanoan, Uto-Aztecan, Athabaskan, Tsimshianic, Natchez, Zuni, Chimariko, Yana, and Takelma (with traces of earlier processes in Muskogean and Yuman). Gerdts (1998) casts the net more widely by defining incorporation a bit less restrictively and includes Algonquian, Muskogean, Siouan, and Tanoan (in addition to a series of non-American languages). Nominal incorporation is attested in Mayan and Totonacan (Mithun 1984, Sullivan 1984, and Levy 1999), and the recent literature on South American languages reports that it is relatively rare in the Andean area but occurs commonly in Amazonia (Adelaar 2004:518). Nominal incorporation of different kinds is found in Mapudungun, Movima, and Yanomami; in Arawakan and Chibchan; in Nambikuara, Tupí-Guaraní, and Tucanoan; and in Cariban, Nadahup, Panoan, Bora-Witoto, Chocoan, and Guahiban (Velupillai 2012:120). A sizable body of literature in the 1980s and 1990s dealt with at least two interesting descriptive and theoretical issues in this context. First, is nominal incorporation best seen as a lexical (i.e., morphological) or as a syntactic phenomenon? Second, to what extent is it comparable to other kinds of incorporation (e.g., adpositional, adjectival, adverbial, verbal)? Incorporation is found in other language families/areas around the globe (see Velupillai 2012:268), but lexical affixation, at least according to our present state of knowledge, much less frequently so-a question that, to my knowledge, linguistic typology has hitherto failed to address systematically.

Phenomena like lexical affixation and nominal incorporation raise issues linked to the observable cline between lexical and grammatical elements and the problematic derivation-inflection opposition. Lexical units include elements of various internal complexity, namely, morphemes, words, phrases, higher-level constructs (e.g., sayings, sentence and text frames), and so on. The received classification of such units is based on morphological and/ or syntactic properties of the different groups they appear to fall into, but semantic-pragmatic factors have usually been taken into account as well.

In the morpheme-based models of morphology ("item-and-arrangement approaches") that have been dominant in the study of indigenous languages of the Americas, morphemes fall into three types. Those belonging to the first group ("roots") can be comparatively long and potentially realize the 
full phonemic spectrum, constitute a large and open partition of the inventory of meaningful elements, and show meanings that range from abstract to concrete (e.g., Gleason 1955:59 and Bauer 1988:11). Those belonging to the second group ("affixes") come close to the mirror image of the former: they are comparatively short and may realize only a subset of the phonemic spectrum, constitute a small and closed portion of the element inventory, and have abstract meanings. The third group is residual: it is intermediate between the other two but lacks a prototype of its own and does not have a generally accepted name: the labels "affixoids" and "semi-affixes" have occasionally been employed (Bergenholtz 1997 and Dixon 2014:chap. 3) to capture the nature of some of these elements, but their use is not widespread and their contours are imprecise. ${ }^{2}$ (The dimensions of morphosyntactic and phonological autonomy are sometimes invoked to distinguish prototypical words from prototypical affixes, but they are relevant in a non-circular way only to the extent that a sizable number of bare roots are bona fide words in individual languages.) Common descriptivist and theoretical practice acknowledges the existence of non-prototypical roots and affixes but does not postulate graded membership for any of these categories and seldom explores the intermediate zone in a systematic way. Present-day scholars who chiefly focus on European languages seldom work with models that deviate in a fundamental way from the one just sketched.

Against this background, it might seem that Boas was merely stating a dated opinion based on fragmentary evidence or a simple misconception on his part when he wrote that a simple and polar definition of roots and affixes is "arbitrary . . . in Algonquin or Kutenai" (1917:6). He develops his argument further, however, in a passage worth quoting in full:

The groups of ideas selected for expression by formative elements are quite distinctive, and they belong to the most important features in the characterization of each language. In some cases they are poorly developed, but most American languages possess an astonishing number of formative elements of this type. In some cases... we are in doubt whether we shall designate one group as subordinate elements, or whether we shall speak of the composition of co-ordinate elements. ... [I]t involves a problem of great theoretical interest; namely, the question whether formative elements have developed from independent words, as has been proved to be the case with many formal suffixes of European languages. (Boas 1917:6)

These lexical affixes described by Boas have to occur bound to other roots, like prototypical affixes. But they also have root-like properties: even though

2 See also Mel'čuk (1993:262-63) for the label "quasi-grammeme" and Kibrik (2005) for its use (as well as "quasi-inflection") in Athabaskan studies. Rather than the word-affix and affixclitic oppositions, Kibrik's proposal addresses the problematic inflection-derivation opposition in the Athabaskan context: "quasi-grammemes are the polysynthetic analog of various adverbs and circumstants in less synthetic languages" (2005:215). 
they belong to a possibly closed class, this class may be quite large; their meaning can be fairly concrete and specific; and they are similar to nouns incorporated into verbs or other nouns - although they seem to have grammaticalized to various degrees - and may actually have originated as incorporates. As outlined by Mithun (1999:48), some express manner (Barbareño Chumash ap- 'rapidly' in s-aqliwin 'she swallows' vs. s-ap-aqliwin 'she gulps down'), some indicate location (Kwak'wala -it 'in the house / on the floor' in teptebi-it 'be shattered on the floor'), and some indicate instruments (Tümpisa Shoshone tsiH- 'with a sharp/pointed instrument' in ka?ah 'break' vs. tsik-ka?ah 'cut'). Gerdts (2003) shows that some can also indicate patients/themes (Halkomelem

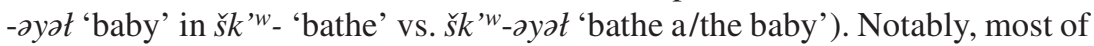
these lexical affixes do have independent root/stem counterparts (with which they systematically coexist) in Salishan and Eskimo-Aleutian; these bound and free "variants" usually differ in meaning, however, the bound elements being more general than the latter ("[t]hey often carry a diverse set of meanings that are linked through semantic extension and abstraction" [Mithun 1999:50]). They also differ in the kinds of uses to which they are put, the former being lexicon-extending, often in highly idiomatic constructions (" $\mathrm{t}]$ hey often serve to background established or incidental information" and "regulate the flow of information" [Mithun 1999:51]).

In what follows, I present some data from one South American (Mapudungun) (2.1) and one North American language (Blackfoot) (2.2), in order to show what we have learned, and what we are still exploring, about morpheme types in such languages. The first section (2.1) centers on subtypes of verbal root-like elements; the second (2.2) also addresses subtypes of verbal root-like elements but focuses on subtypes of verbal affix-like elements. I then zoom out for a general perspective on the issues involved (2.3).

2.1. Verbal root-like morphemes in Mapudungun. Mapudungun (ISO code: arn), an unclassified language of south-central Chile and west-central Argentina, does not show the abundance of lexical suffixes that Salishan, Wakashan, or Eskimo-Aleutian languages have. It does, however, show an interesting array of verbal roots/stems that are incorporated into other verbs - a possibility that has probably emerged at different points for different items, some in pre-contact times and others more recently. ${ }^{3}$ First consider the verbal complex ütrüfentukünuparkei in (1): ${ }^{4}$

${ }^{3}$ The language shows productive nominal incorporation (see Harmelink 1992, Baker, Aranovich, and Golluscio 2005, and Zúñiga, forthcoming), but all derivational affixes seem to have verbal etymons.

${ }^{4}$ The abbreviations used in the interlinear glosses and elsewhere are the following: $\mathrm{AI}=$ animate intransitive, $\mathrm{ANIM}=$ animate, $\mathrm{ART}=$ article, $\mathrm{AUX}=$ auxiliary, $\mathrm{CAUS}=$ causative, $\mathrm{CIS}=$ cislocative, $\mathrm{DEM}=$ demonstrative, $\mathrm{DIR}=$ direct, $\mathrm{DUR}=$ durative, $\mathrm{F}=$ feminine, FUT $=$ future, $\mathrm{II}=$ inanimate intransitive, IMPER $=$ imperative, INAN $=$ inanimate, IND $=$ indicative, INF $=$ infinitive, 
(1) Fey ütrüf-entu-künu-pa-rke-i fentren fill-ke

then throw-remove-leave-CIS-REP-IND many each-NSG

challwa.

fish

'Then he took many and varied fishes out [of the water], threw them [onto the shore] and left them [there], it is said'. (Salas 2006:204)

Any of the three verb roots occurring at the beginning of the predicate can occur alone and independently of the others, but all of them appear in a complex verb stem in (1), to which the rest of the morphology is added in order to arrive at a full-fledged verbal word. ${ }^{5}$ The first of the three (ütrüf- 'throw') can be seen as the main lexical verb, while the others are possibly subsidiary. The second one (entu- 'remove') belongs to a (probably closed) class of motion verbs, and the last one (künu- 'leave, set') expresses aspectuality and causation (and probably also belongs to a closed class). The meaning of the first root is not limited or restricted in any way when compared to occurrences as the sole root of the verb-but neither are the (already quite abstract) meanings of the verbs falling in the second and third slots. Interestingly enough, the fillers of the first two slots have to agree in transitivity (here, the two roots are transitive); the filler of the third slot is transitivity-insensitive (more precisely: it combines with intransitive and transitive stems and actually determines the transitivity of the resulting macro-stem). ${ }^{6}$ Lastly, the cislocative -pa is usually thought to come from the root küpa- 'come', like the translocative - $p u$,

INTENS $=$ intensifier, INV $=$ inverse, ITR $=$ intransitive, NEG $=$ negative, NMLZ $=$ nominalizer, NSG $=$ non-singular, $\mathrm{P}=$ patientive argument of transitive verb, $\mathrm{PA}=$ Proto-Algonquian, $\mathrm{PL}=$ plural, PROG $=$ progressive, PROX $=$ proximate, PSR $=$ possessor, PST $=$ past, $\mathrm{PTCP}=$ participle, REFL $=$ reflexive, $\mathrm{REP}=$ reportative, $\mathrm{RES}=$ resultative, $\mathrm{RR}=$ relative root, $\mathrm{SG}=$ singular, $\mathrm{TA}=$ transitive animate, TAM tense-aspect-mood, $\mathrm{TI}=$ transitive inanimate, TRANS $=$ translocative, $\mathrm{VBLZ}=$ verbalizer. Mapudungun examples are given in their underlying phonological forms here; some (minor) resyllabification, elision, and epenthesis rules apply in order to arrive at surface forms. The orthographic convention used is the Alfabeto Mapuche Unificado; most symbols have their IPA values, but $\ddot{u}$ represents the vowel [ə] [i], ey and ew represent the diphthongs [eI] and [ev], respectively, and the other vowels have a value similar to the ones they have in Chilean Spanish. $r$ and $t r$ represent retroflex sounds, $c h$ is a voiceless palato-alveolar affricate, $\tilde{n}$ is a voiced palatal nasal, and $l l$ is a voiced palatal lateral approximant. Underlined letters represent interdental consonants.

5 Such complex predicates have been labeled root serialization by the typological literature. In other kinds of serial verb constructions, the individual verbs are (at least partly) autonomous grammatical words (see Bisang 2009).

${ }^{6}$ Künu- 'leave, set' can have other functions in complex stems (see Moesbach 1962:187-88). With the reflexive suffix $-w$, it means 'become' (e.g., kono-künu-w- [Chilean.pigeon-leave-REFL-] 'turn into a Chilean pigeon'); with verbs that do not denote change of state, it means 'help' (e.g., tu-kawell-künu- [take/grab-horse-leave-] 'help take hold of the horse'). 
whose etymon is thought to be $p u$ - 'arrive there'. Neither the cislocative nor the translocative marker shows allomorphy of any kind.

By contrast, -küle in (2a) is probably a grammaticalized version of the root müle- 'be (temporarily), exist, live' ( $2 b)$ :

(2a) Lef-küle-n amu-i pangko-a-fi-lu. run-PROG-INF go-IND hug-FUT-3P-PTCP

'He ran (lit., went running) in order to hug her'. (Salas 2006:242)

(2b) Feymew ina lewfü müle-i pu che. then on.bank river be-IND PL person

'There lived people on the river bank back then'. (Salas 2006:209)

The element -küle comes in two allomorphs (-le post-vocalically and -küle elsewhere), and the meaning of the bound form, either progressivity or resultativity (Zúñiga 2001), is arguably descended from the meaning of the independent root via semantic bleaching. The perambulative -yaw -kiyaw (< miaw - 'walk') shows both similar allomorphy and similar bleaching of its semantics.

Other root-like elements show yet other kinds of behavior. First, meke- 'be engaged in' has been recruited from forms like $(3 a)$ as a suffix to mark the progressive in those like ( $3 b)$ - perhaps rather recently: it shows no allomorphy, it can still take an infinitival complement, and it requires an agentive subject (*mawün-meke-i is rejected by speakers as possible expression of 'it's raining'; mawün-küle-i or the periphrastic petu mawün-i with petu 'still' are used instead):

(3a) Meke-i lef-n.

be.engaged-IND run-INF

'S/he is running'. (my field notes)

(3b) Lef-meke-i.

run-PROG-IND

'S/he is running'. (my field notes)

(3c) Feymew kisu lef-trepe-rke-i.

then same run-awaken(ITR)-REP-IND

'Then he immediately woke up, they say'. (Salas 2006:240)

Second, lef- 'run' can occur either as the sole root $(2 a$ and $3 b)$ or preceding what is arguably the main root of the verbal complex $(3 c) .{ }^{7}$ Similar elements

${ }^{7}$ Some older speakers seem to allow verb stem serialization/compounding of a more liberal type, for example, witra-lef-tripa-meke- (rise-run-exit-PROG-) 'to spend a while rising and running out' (Salas 2006:173), where two predicates (witra- and lef-tripa-) have been coordinated 


\begin{tabular}{|c|c|c|c|c|c|c|c|}
\hline $\mathrm{V}_{-1}$ & $\mathrm{~V}_{0}$ & $\mathrm{~V}_{1}$ & $\mathrm{~V}_{2}$ & $\mathrm{~V}_{3}$ & $\mathrm{~V}_{4}$ & $\ldots$ & $\mathrm{V}_{\mathrm{F}}$ \\
\hline (varied) & root & deixis & aspect & aspect & direction & & inflection \\
\hline
\end{tabular}

FIG. 1.-Selected slots of the Mapudungun verbal template.

include kim- 'know how to' < 'know' but also küpa- 'want' < 'come'. ${ }^{8}$ The element pepi- 'can' was able to function as a root a century ago (taking an infinitival complement) (Augusta 1916:170), but nowadays it is a prefix without a verbal alternant:

(4) Tañi ñuke pepi-trepe-l-la-fi-n.

1SG.PSR mother can-awaken(ITR)-CAUS-NEG-3P-1SG.IND

'My mother I was unable to awaken'. (Salas 2006:262)

Comparable elements include the obsolescent causative kalli- (< kalli- 'leave', no longer in use), but note that this leftmost slot in which pepi- occurs also hosts 2-3 elements without a known etymology (e.g., the obsolete distributive kepi-).

Thus, Mapudungun shows several kinds of root-like elements. They occupy different templatic positions in the schema presented in figure 1.

First, DEFAULT ROOTS (e.g., ütrüf- 'throw') can only occur as the sole root of predicates and show no allomorphy whatsoever. Second, there are two kinds of elements preposed to such roots; some can occur as sole roots themselves and can be called PRE-COMBINABLE ROOTS (e.g., kim- 'know'), while others cannot do so and are FOSSILIZED ROOTs (e.g., pepi- 'can'). Third, there are several kinds of elements postposed to default roots; they are distinguished by the slot in which they can occur (with those farther away from the default root arguably showing stronger semantic bleaching) but also by the allomorphy they display. Post-combinable roots like künu- 'leave, set', meke- 'be engaged; PROGRESSIVE', and pu- 'go; TRANSLOCATIVE' have none, whereas those like tripa- 'exit' show grammatically conditioned allomorphy (requiring the causativizing of intransitives or suppletive transitive forms), and those like müle- 'be, exist; PROGRESSIVE/RESULTATIVE' show phonologically conditioned allomorphy that differs from the allomorphy of default affixes (i.e., the trimming of the root and the insertion of a $k \mathrm{~V}$ syllable). Lastly, there are elements like küpa- 'come; want; CISLOCATIVE', which I call HYBRIDS here; they can occur as sole roots but may also be preposed and postposed, in the latter case with a reduced stem but no allomorphy. For comparison, only DEFAULT AFFIXES like indicative $-i$ and nonfinite $-n$ are given in figure 2 , which summarizes

on an arguably context-specific basis. Such examples are seldom found in narrative texts, and younger speakers disfavor them in elicitation.

${ }^{8}$ This usage of küpa-preceding the main root is now obsolescent; its uses as main root itself or as cislocative are robust. 


\begin{tabular}{|c|c|c|c|}
\hline & $\begin{array}{l}\text { Sole root } \\
\left(\mathrm{V}_{0} \text { slot }\right)\end{array}$ & Other slot & Allomorphy \\
\hline $\begin{array}{l}\text { Default roots } \\
\text { ütrüf- 'throw' }\end{array}$ & $\checkmark$ & $x$ & $x$ \\
\hline $\begin{array}{l}\text { Fossilized roots } \\
\text { pepi- 'can' }\end{array}$ & $x$ & $\mathrm{~V}_{-1}$ & $x$ \\
\hline $\begin{array}{l}\text { Pre-combinable roots } \\
\text { kim- 'know' }\end{array}$ & $\checkmark$ & $\mathrm{V}_{-1}$ & $x$ \\
\hline $\begin{array}{l}\text { Post-combinable roots } \\
\text { - tripa- 'exit' } \\
\text { - künu 'leave, set' } \\
\text { - meke- 'be engaged; PROG' } \\
\text { - müle- 'be, exist; PROG/RES' } \\
\text { - pu- 'go; TRANs' }\end{array}$ & $\begin{array}{l}\checkmark \\
\checkmark \\
\checkmark \\
\checkmark \\
\checkmark\end{array}$ & $\begin{array}{l}\mathrm{V}_{1} \\
\mathrm{~V}_{2} \\
\mathrm{~V}_{3} \\
\mathrm{~V}_{3} \\
\mathrm{~V}_{4}\end{array}$ & $\begin{array}{c}\text { gr.c. } \\
\mathbf{x} \\
\mathbf{x} \\
\text { ph.c.: }(+k \mathrm{~V}) \\
\mathbf{x} \\
\end{array}$ \\
\hline $\begin{array}{l}\text { Hybrids } \\
\text { küpa- 'come; want; cIs' }\end{array}$ & $\checkmark$ & $\mathrm{V}_{-1}+\mathrm{V}_{4}$ & $x$ \\
\hline $\begin{array}{l}\text { Prototypical affixes } \\
-i \text { 'IND' / - } n \text { 'INF/NMLZ' }\end{array}$ & $x$ & $\mathrm{~V}_{\mathrm{F}}$ & $\begin{array}{l}\text { ph.c. (epe/ } \\
\text { resyll) }\end{array}$ \\
\hline
\end{tabular}

FIG. 2.-Mapudungun root-like elements and prototypical affixes.

the properties of all these elements; the default root has been placed in the slot $\mathrm{V}_{0}$, with the preposed elements occupying slot $\mathrm{V}_{-1}$ and those postposed occupying slots $\mathrm{V}_{1}$ to the final $\mathrm{V}_{\mathrm{F}} \cdot{ }^{9}$

Mapudungun root-like elements show that there is no simple cline leading from default roots to default (derivational) affixes. The issue of how much of their own argument structure the grammaticalized versions retain is perhaps one of the simplest problems in this context: default roots are typically the elements determining the overall valency of the complex stem; only in complexes with künu- 'leave, set' is it the "other root-like element" that overrides the others.

2.2. Verbal root-like and affix-like morphemes in Blackfoot. The traditional model of Algonquian verb morphology (Bloomfield 1946) still in use today distinguishes, from left to right, inflectional prefixes, preverbs, initials, medials, finals, and inflectional suffixes; this is schematically summarized in figure $3 .{ }^{10}$

${ }^{9}$ There are a number of positions between the fourth root-like element and the final affixes; see Zúñiga (2000; 2006) and Smeets (2008) for details.

${ }^{10} \mathrm{I}$ am glossing over a number of problems here, including what Bloomfield identified as post-initial, pre-medial, post-medial, and pre-final elements (originating basically, but not exclusively, from the difficulty in segmenting some verb stems in an exhaustive way equipped solely with the initial-medial-final model). 


\begin{tabular}{|l|c|c|c|c|c|}
\hline inflection & preverb(s) & initial & medial & final(s) & inflection \\
\hline & & \multicolumn{4}{|c|}{ verb stem } \\
\hline
\end{tabular}

FIG. 3.-Simplified model of Algonquian verb structure.

Inflectional prefixes include TAM information and an index for one of the syntactic arguments. Preverbs can occupy several slots and are heterogeneous: they include inflectional prefixes (negation, tense, aspect), prefixes that correspond to clausal auxiliaries in European languages (e.g., modals), and elements that express source, location, extent, degree, quantity, or manner; they can also occur as roots in their own right and are usually called relative roots in Algonquian studies. Initials are usually seen as "default verbal roots"; ${ }^{11}$ medials are lexical suffixes (including body-part expressions, classificatory elements, and goal expressions); finals are suffixes that minimally set up a quadripartite classification of verb stems according to transitivity and grammatical animacy (these are the "abstract" finals: II inanimate intransitive, AI animate intransitive, TI transitive inanimate, TA transitive animate) and maximally also add non-negligible semantics (these are the "concrete" finals, including voice markers and elements approximately corresponding to light verbs in other languages, which shall concern us further in what follows). It is important to note that these three labels (initial, medial, final) refer to particular slots, rather than to their fillers (even though there is some specialization in this respect, as I show below). For instance, Bloomfield (1946:103) explicitly mentions that the Cree element api 'sit' could appear as either an AI stem = root+final (in isih-api-w 'and thus he sits', where isih- 'thus, so' is a preverb) or as an AI final (in it-api-w 'he sits so', where it- '(be) thus, so' is the root). Lastly, inflectional suffixes encode person, number, and/or gender/obviation of syntactic arguments, in addition to TAM-related information and other categories.

A comprehensive critique of the adequacy of such a model lies beyond the scope of this paper. Suffice it to say that root-like elements show considerable variation in their syntagmatic and paradigmatic properties; the following examples from Blackfoot (ISO code: bla) (Plains Algonquian; Alberta and Montana) illustrate the main groups. ${ }^{12}$ First, elements like sin- 'lick' can be regarded as default verb roots in several respects: they can occur as the sole root of a word, do not occur either as preverbs or as finals, and do not show any allomorphy (5):

${ }^{11}$ I do not address the issue of nominal initials in Algonquian here.

${ }^{12} \mathrm{I}$ am glossing over the largely poorly understood issue of tone assignment on Blackfoot verbs. The orthographic convention employed here is the one used in Don Frantz's publications, which occasionally employs $M, N$, and $S$ for "non-permanent" $m, n$, and $s$, respectively (i.e., segments that Frantz analyzes as present in underlying forms but surfacing only before some suffixes), and $I$ for an $i$ segment that participates in some specific morphophonemic processes. 
(5) Nitsí́sinihtaki.

nit-ii-sin-ihtaki

1-PST-lick-AI

'I licked (something)'. (Frantz and Russell 1995:210)

Elements like ohkott- 'can' are almost their mirror image: they do not have allomorphs but occur as preverbs only (6). (Comparable items include ssáak'try', ipiitsiy- 'begin', Iksistt- 'finish', yaahs- 'enjoy, like', ohko- 'have (something) for', and mato- oto- 'go to'.) ${ }^{13}$

(6) Iihkóttsipiima.

ii-ohkott-ipii-m-wa

PST-can-enter:AI-DIR-PROX:SG

'S/he was able to enter'. (Frantz and Russell 1995:143)

Yet other elements, like the stem -oo- 'go (AI)' and the root -ip- 'bring', are formally invariant but need a preverb to occur (note so- 'into the water' in $7 a$ and poohsap- 'hither' in $7 b$ ); the latter element can also occur (in its TA form $i p-i$-) as a causative when combined with whole verb stems (here: okska'si- 'run (AI)') (7c):

(7a) Nítssowóo.

nit-ii-so-oo

1-PST-into.water-go:AI

'I walked into the water'. (Frantz and Russell 1995:219)

(7b) Póóhsapípohtoot!

poohsap-ip-ohtoo-t

hither-bring-TI-IMPER:SG

'Bring it here!' (Frantz and Russell 1995:75)

(7c) Nitáóksa'sí́piooka.

nit-á-okska'si-ip-i-ok-wa

1-DUR-run:AI-bring-TA-INV-PROX:SG

'S/he (PROX) makes me run'. (Frantz and Russell 1995:70)

While some relative roots are invariable (e.g., sstaan- 'instead of', waahtso'in place of', and itap- 'toward'), other elements that need to occur preceding a verb stem show grammatically conditioned allomorphy that default roots

${ }^{13}$ Preverbs expressing temporal, aspectual, and modal meanings are found, with considerable functional uniformity, in Algonquian languages of all three geographic groups (Plains, Central, and Eastern). Only a limited number of those found in other languages appear to be cognate with the Blackfoot elements.

Such elements differ from those with similar semantics like soka'pii- (II) 'be good', ssksini(TI) 'know', waanit- (TA) 'tell', sstaa- (AI) 'want', and omai'tsi- (TI) 'believe', which do occur as roots of superordinate predicates taking a complement in the conjunctive form. 
never show. The relative root ohp-, for instance, appears as omohp- when immediately following person prefixes and as iihp-word-initially; ${ }^{14}$ it accommodates what is arguably an overt instrumental or comitative secondary object in the clause (8). (The relative root oht- has a broader semantic range but shows the same kind of allomorphy.)

(8) Áakohpinnisiyaawa omi sináákiatsisi. $\begin{array}{lll}\text { yáak-ohp-innis-i'yi-yi=aawa } & \text { om-yi } & \text { sináákia'tsiS-yi } \\ \text { FUT-RR:with-fall-AI-PL=3PL } & \text { DEM-INAN:SG } & \text { book-INAN:SG }\end{array}$

'They will fall with that book'. (Frantz 2009:92)

The locative relative root it-, by contrast, appears as ist- with imperatives; with this and poohsap- 'hither', the secondary object NP can be either covert (with a general meaning of 'there/then') or overt, as in (9): ${ }^{15}$

(9) Itáóyiwa nookóówayi.

$$
\begin{array}{ll}
\text { it-á-OO-i-wa } & \text { n-ookóówa-yi } \\
\text { RR:at-DUR-eat-AI-PROX:SG } & \text { 1.PSR-home-INAN:SG } \\
\text { 'S/he (PROX) eats at my place'. (Frantz 2009:94) }
\end{array}
$$

This sketch of the variation found with root-like elements in Blackfoot is schematically summarized in figure 4 . Note that medials usually stand in paradigmatic opposition to verb-external nouns, like -ssk $\sim$ mosstoksísi 'face'. A significant renewal of the nominal lexicon apparently left most medials in a suppletive(-like) relationship with their independent nominal counterparts. Finals belong to several subgroups: agreeing (e.g., TA $-i$ ) and deriving (e.g., AI -aki) abstract finals, ${ }^{16}$ as well as concrete finals (e.g., the causative TA -áttsi and the element -iht, discussed below).

Let us now take a closer look at the different kinds of finals by considering words built on the default root sin- 'lick'. As with many other roots, derived stems appear in triplets when the appropriate finals are suffixed. In this case, these are -ihtaki (AI), -ihtsi (TI), and -ip (TA), which Frantz calls "instrument finals" because they "indicate the instrument (usually a body part) involved" (2009:99). Notably, the former two appear to be further segmentable as -iht-aki

${ }^{14}$ Frantz (2009:92) further mentions idiolectal variation for the allomorph occurring after the person-marking prefix, namely, omohp- o'ohp- oohp-.

15 The element ohtaahtsiwa- 'in place of' (Frantz 2009:93), apparently related to the preverb waahtso- 'in place of', seems to show an allomorphy similar to that of the general relative root oht-.

16 See Goddard (1990) for the opposition between primary and secondary derivation in Algonquian in general and Armoskaite (2011) and Genee (2013) for the opposition between agreeing and non-agreeing (= deriving) finals in Blackfoot in particular. The term "agreeing" refers to the fact that the initial is seen as intransitive or transitive and the final has a matching value in these cases; "non-agreeing" or "deriving" finals, by contrast, change the transitivity value of the root/stem they attach to. 


\begin{tabular}{|c|c|c|c|}
\hline & Sole root & Other slot & Allomorphy \\
\hline $\begin{array}{l}\text { Default roots } \\
\text { sin- 'lick' }\end{array}$ & $\checkmark$ & $x$ & $x$ \\
\hline $\begin{array}{l}\text { Preverbal roots } \\
\text { ohkott- 'can' }\end{array}$ & $x$ & pre-root & $x$ \\
\hline $\begin{array}{l}\text { Bound roots } \\
\text {-oo- 'go (AI)' (stem) } \\
\text {-ip- 'bring' }\end{array}$ & $\begin{array}{l}x \\
x\end{array}$ & $\begin{array}{c}x \\
\text { final }\end{array}$ & $\begin{array}{l}x \\
x\end{array}$ \\
\hline $\begin{array}{l}\text { Relative roots } \\
\text { oht- 'with' } \\
\text { it- 'there, then' }\end{array}$ & $\begin{array}{l}x \\
x\end{array}$ & $\begin{array}{l}\text { pre-root } \\
\text { pre-root }\end{array}$ & $\begin{array}{l}\text { gr.c. } 1 \\
\text { gr.c. } 2\end{array}$ \\
\hline $\begin{array}{l}\text { Medials } \\
\text {-ssk'face' }\end{array}$ & $x$ & V-external & gr.c. 3 \\
\hline $\begin{array}{l}\text { Abstract finals } \\
-i \text { 'TA' } \\
-a k i \text { 'AI' }\end{array}$ & $\begin{array}{l}x \\
x\end{array}$ & $\begin{array}{c}x \\
2 \text { slots }\end{array}$ & $\begin{array}{l}x \\
x\end{array}$ \\
\hline $\begin{array}{l}\text { Concrete finals } \\
\text {-iht 'by mouth' } \\
\text {-áttsi 'TA:CAus' }\end{array}$ & $\begin{array}{l}x \\
x\end{array}$ & $\begin{array}{l}x \\
x\end{array}$ & $\underset{x}{\text { ph.c }}$ \\
\hline
\end{tabular}

FIG. 4.-Blackfoot root-like elements and selected affixes.

and -iht-i respectively, composed of a morpheme -iht that arguably expresses the meaning 'by mouth' and the common deriving finals -aki (AI) and $-i$ (TI), which occur as sole finals with other initials (note omai't-aki- (AI) and omai' $t-i$ - (TI), both 'believe'). While -iht is not related to the noun maoó-yi or the medial -oyi- (both 'mouth'), ${ }^{17}$ recognizing this element as a separate morpheme is not speculative: there is an almost exact counterpart in the triplet sikstaki- (AI), sikstsi- (TI), and siksip- (TA) (all 'bite'), while sonai'ssk-iht-ak(i)-(n)aato-iksistsiko 'New Year's Day (lit., kissing holy day)' and sonai'-ssk-ip- 'kiss (TA)' confirm the paradigmatic opposition between AI -iht-aki and TA -ip. Work on the historical development of Algonquian also supports this analysis: Bloomfield (1946) reconstructs PA *sak- 'seize' and PA *sakipw - 'bite', which leads Proulx (1985) to postulate a PA medial *-(i)pw and even a Proto-Algic medial $*_{-V}$ V $p$ 'by tooth, bite, eat'. Thus, the presentday Blackfoot final -ip arguably stems from a medial.

This leads us back to Boas's question about the origin of bound material on verbs-first for Algonquian, then for indigenous languages of the Americas in general. We have no reason to doubt that most Algonquian initials have verbal etymons, and at least some medials seem to have nominal etymons. Finals are numerous in all languages, and substantiating cognacy for them

17 There is also an apparently unrelated bound AI stem -iht-aki- meaning 'place' (Frantz and Russell 1995:23). 
is an illuminating but quite daunting task. Rhodes (2016) makes a strong synchronic case for seeing the initials and finals of Southwestern Ojibwe in a new light: most verbal roots are bound and belong to a clearly open class (he suggests they originated from "independently occurring adverb roots or even recycled verb stems"), while finals are "the real verbs" (because they determine stem transitivity), although they are equally, if not more, bound and belong to what is clearly a closed class (that is nevertheless sizable - approximately 200 items for the Ojibwe variety under study). ${ }^{18}$ Thus, to Valentine's judgment that "[t]he boundary between the preverb and initial position [in Ojibwe] is relatively porous" (2001:424), we can add that the boundary between medial and final appears to be porous as well.

2.3. The typology and the origins of verbal morphology. Mapudungun has no known relatives, ${ }^{19}$ and its present-day (and, as far as we know, contact-day) neighbors show verb morphologies of varied complexity that are nonetheless quite different from the Mapudungun structures outlined above. Mapudungun residual-type morphemes consist of root-like elements of verbal origin that come in different forms and show different degrees of grammaticalization. Nominal roots (either alone or in stems, compounds, or even NPs) can occur within verbal complexes but do not show any trace of phonetic or semantic erosion. By contrast, Blackfoot clearly belongs to the Algonquian family, and its structures show close parallels to those found in related languages. Essentially, the Blackfoot residual morpheme type also consists of root-like elements of verbal origin that come in different forms and show different degrees of grammaticalization-but, unlike in Mapudungun, there are numerous affix-like elements of verbal/nominal origin, also showing different degrees of grammaticalization, and erosion of many such elements appears to be pervasive. In addition, present-day nominal roots do not normally occur within the verbal complex, and erstwhile nominals do not express patients/themes but instead notions related to instruments, locations, and manners.

There are some interesting parallels in languages currently spoken not far away from Blackfoot. One of the structural hallmarks of some Hokan, Penutian, and Siouan languages is their numerous "bipartite verb stems," that

${ }^{18}$ Working in a Chomskyan framework, Déchaine and Weber (2015) postulate a template for Blackfoot complex stems with up to three positions-a root, a transitivizing suffix (the final proper; head of $v \mathrm{P}$ ), and an animacy-encoding suffix (the "theme marker"; head of VP). Accordingly, for the example in (5), they see sin- 'lick' as a transitive root, -ip 'by mouth' as the $v$, and a following zero suffix as the $\mathrm{V}$ that derives TA stems (TI and AI stems are derived from the same root by suffixing the $v$-V sequences $-i h t-i$ and -iht-aki, respectively).

${ }^{19}$ Possible genealogical links have been mentioned in the literature, including those with languages of Patagonia, languages of eastern Bolivia, Panoan, Takanan, Arawakan, and Mayan, but they have not been substantiated. 
is, verb stems that behave like indivisible units according to some morphosyntactic criteria but are segmentable according to others. Provided that we allow for prefixes (rather than suffixes, as in Algonquian) to determine overall transitivity, such stems are analogous to the Algonquian complex initial-final units-for instance, the bipartite stem nahiprye- 'paddle downstream (AI)' in Penobscot $\dagger$ (ISO code: aaq) (Eastern Algonquian; Maine), consisting of the bound initial nah- 'downstream' and the bound AI final -pəye 'move by paddling (AI)' (Quinn 2009). Jacobsen (1980) linked the phenomenon as found in Washo (ISO code: was) (unclassified/Hokan; California and Nevada) explicitly to lexical affixation in Salishan, and DeLancey $(1996 ; 1999 ; 2000)$ explored its occurrence in some languages of California and Oregon, dealing especially with it in Klamath $\dagger$ (ISO code: kla) (Plateau Penutian).

Such bipartite stems come in several guises. We can distinguish at least instrumental stems like ncapka 'mash up with a round instrument' (from $n$ 'act with a round instrument' and $c a b k$ ' 'mash up something mushy'), classificatory stems like neqya 'flat object in the road' (from $n^{e}$ 'flat object' and eqy 'in the road'), and motion stems like howwa 'jump (singular actor) into water' (from hod 'jump (singular actor)' and ew 'water') (DeLancey 1999). Both Jacobsen and DeLancey suggest that the former two may be the product of an older development, whereas the third type is probably more recent. More precisely, DeLancey suggests for Klamath that the old instrumental prefixes may have been nominal and/or verbal, that the old classificatory prefixes were probably originally nominal incorporates, and that the recent motion predicates are the product of fossilized $\mathrm{V}+\mathrm{V}$ compounding.

This raises two issues most relevant for our current purposes. First, the widespread simple version of the bipartite morpheme-type model (roots vs. affixes) does justice neither to the synchronic complexity nor to the synchronic intricacies encountered in natural languages. Even though Americanists are well aware of this, morphological theory and morphological typology have not yet developed principled alternatives that would take the challenges seriously enough and transcend the boundaries of local studies. ${ }^{20}$ Mithun (1999:49) cautiously says that Salishan and Eskimo-Aleutian suffixes' concrete meanings might suggest that the usual form-meaning associations-roots carrying the central meaning of words and affixes modifying roots, typically in abstract ways-are not universal. Put differently, Boas definitely seems to have been on the right track, and now that present-day specialists have more information

20 As aptly mentioned by an anonymous reviewer, Rice (2000) and Sadock (2012) (based on Athabaskan and Eskimoan, respectively) do take several of the challenges seriously and constitute highly developed and principled alternatives to a simple roots-and-affixes model of morphology. To my knowledge, however, these proposals have not yet inspired equally comprehensive parallel studies for other well-known language families of the Americas, let alone for indigenous languages of the Americas in general. 
available to them they would agree-but linguistic studies have probably not yet used the extant evidence as radically as needed.

Second, DeLancey's studies on synchronic and diachronic aspects of verb morphologies in some languages spoken on the West Coast of the United States lead us back to Boas's concern about languages from different families borrowing structural features from each other, thereby obscuring genealogical connections. The knowledge about different kinds of bound elements and different kinds of elements that carry the main semantic load (including argument structure) has indeed informed a substantial part of language- and family-specific studies in North America; suffice it to mention the work on incorporation and lexical affixation in Athabaskan, Iroquoian, and Salishan but also especially in Eskimo-Aleutian (Woodbury 1975, Fortescue 1980, Mithun 1997, Gerdts 2003, and Uchihara 2014). ${ }^{21}$ Nevertheless, such work is comparatively recent (not much older than Jacobsen's seminal study [Jacobsen 1980]), and comparable in-depth studies are still to be undertaken for other well-established and reasonably well-known American indigenous families, like Uto-Aztecan, Mayan, Oto-Manguean, Arawakan, Quechuan, and TupíGuaraní. Furthermore, studies that aim at disentangling areal and genealogical correspondences have tended to be too specific and too scarce, even for North American languages. Thus, much more work in the vein of DeLancey's is needed in order to arrive at a more complete picture of the phenomena involved, their distribution, and their probable history.

3. Words. Regarding the notion of "word," two brief statements of Boas's are particularly noteworthy. First, "[t]he distinction between verb and noun [in North American languages-FZ] may be different from ours" (1917:6). This refers to the fact that some North American languages seem to work with an inventory of word groups that differs from the one(s) familiar from western Indo-European languages. I deal with word classes in 3.1 below.

Second, "American languages may furnish us with much important material that emphasizes the view that the unit of human speech as we know it is the sentence, not the word" (Boas 1917:7). This is related to the idea, widespread in the early twentieth century, that indigenous languages of the Americas have a "holophrastic structure." This was tantamount to saying that polysynthesis was rampant in the languages of the region-but note that polysynthesis was equated with the fact that American translational equivalents of "European sentences" apparently were predicative words that included elements expressing arguments or adjuncts in addition to tense, aspect, mood, polarity, and direction. I touch on the role that different aspects

${ }^{21}$ See also some early seminal papers for other languages: Merlan (1976) on Modern Nahuatl and Allen, Gardiner, and Frantz (1984) on Southern Tiwa. 
of morphological structure may play in determining genealogical relatedness only briefly in the concluding section of this article; in this section, I would like to focus on the idea that morphosyntactic theories could, and maybe should, reconsider the adequacy of its basic unit of study. ${ }^{22}$ I frame this discussion in terms of "wordhood domains" (3.2). Section 3.3. summarizes the findings of 3.1 and 3.2 and their significance.

3.1. Word classes. Western literature has labeled different kinds of words "parts of speech" (going back at least to Plato's Cratylus), "lexical categories" (widely used in functional-typological linguistics), "grammatical categories" (chiefly in Chomskyan linguistics), "grammatical classes," "lexical classes," and "word classes." ${ }^{23}$ Much has been written during the twentieth century about the twofold issue of $(i)$ whether all languages have, with relatively minor nuances, the same inventory of such groups, and (ii) whether there is only one inventory from which all natural languages select specific groups, perhaps combining them in idiosyncratic ways.

Accepted Eurocentric models of such groups typically operate with clearcut word classes, whose members are built on specialized roots and show similar morphological and syntactic properties. For instance, nominal roots form nouns, which have specific inflectional categories associated to them (e.g., gender, case, number) and occupy a particular position in NPs, which in turn express arguments of predicates, and so on. Similarly, verbal roots form verbs, which have (other) specific inflectional categories (e.g., tense, aspect, mood, person but also number) and occupy a very different position in the clause, namely, as its head, and so on. In order to use nouns as verbs, they normally need to be verbalized; verbs have to be nominalized in order to be used as nouns.

This Eurocentric model works rather well for Mapudungun: this language has nominal roots like wentru 'man', which normally appear underived as heads of referring expressions like chi wentru 'the man' but require verbalizing morphology if they are to work predicatively, for example, wentru-nge$i$ (man-VBLZ-IND) 'he is a man'. Similarly, verbal roots like weyel- 'swim' normally form predicative expressions like weyel-i (swim-IND) 's/he swam' without further derivational morphology but require a nominalizing element if they are to work referentially, for example, ñi weyel-n (1SG.PSR swim-IND/ NMLZ) or ñi weyel-el (1SG.PSR swim-NMLZ), both 'my swimming'.

22 This is especially relevant for word-based approaches ("word-and-paradigm") but also for lexeme-based approaches ("item-and-process") and the dominant morpheme-based approaches ("item-and-arrangement").

${ }^{23}$ Interestingly enough, some non-European linguistic traditions also postulate parts of speech of the familiar kind: before Pāninini, Yāska (possibly sixth-fifth century в.c.) distinguished nouns (including adjectives), verbs, prefixes, and particles (including prepositions) for Sanskrit in the Nirukta. 
In Nuxalk (ISO code: blc) (Salishan; British Columbia), by contrast, roots like $\lambda i k m$ and $w a c$ ', approximately translatable as 'run' and 'dog', respectively, can occur in either predicative or referring expressions without derivational morphology:

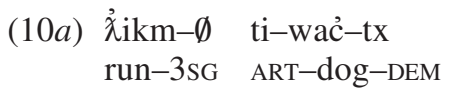

'The dog is running'. (Davis and Saunders 1984:209)

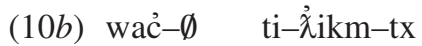

dog-3SG ART-run-DEM

'The one (who is) running is a dog'. (Davis and Saunders 1984:210)

The simplest version of the challenge to the traditional view consists in saying that most roots in languages like Nuxalk are not specialized for individual word classes (the literature has called such roots "precategorial" and "transcategorial") and therefore they differ non-trivially from their Latin, Ancient Greek, or Mapudungun "translational equivalents." Alternatively, some of the systematic non-traditional cases can be analyzed by postulating pervasive zero-derivation or conversion, which then would allow for a flexible handling of lexical items in phrases and clauses. Empirical evidence that has figured prominently in making the case against the accepted classification has come from languages of the Americas but also from Austronesian languages (especially Oceanic) and to some extent from Austro-Asiatic languages (especially Munda). North American languages particularly, most notably from the Northwest Coast groups Wakashan, Salishan, and Chimakuan, have been repeatedly discussed in this context and continue to inspire in-depth studies (Mithun 1999:56-67 and Beck 2013); other groups that have received considerable attention at different points are Iroquoian (Sasse 1998 and Mithun 2000) and Tupí-Guaraní (Queixalós 2006).

Boas's tentative suggestion cited above is not as extreme as it may sound, since he nevertheless assumes the existence of nouns and verbs, and postulates some distinction between them, both in European and in American indigenous languages. His stance is similar to some analytical ideas from the 1980s and 1990s, which claimed, for instance, that some languages have word classes defined in their lexicon, with subsequent morphosyntactic reflexes, while others have word classes defined in their morphology, or perhaps only in their syntax (e.g., Sasse 1998). Hoijer's view of Tonkawa $\nmid$ (ISO code: tqw) (unclassified; Texas) is more radical: "To apply the classificatory notion of 'parts of speech' to Tonkawa would be to do extreme violence to the spirit of the language. It is much more in accord with this feeling to divide all words into two very general classes: independent themes that can stand alone, and themes which must be completed in meaning by one or more affixes" (Hoijer 1931/1933:24). 
Among the attempts to make such no-nouns-and-verbs analyses attractive, Sasse's (1998) application of such a framework to Cayuga in particular and Iroquoian in general deserves special mention. Most mainstream Americanists nowadays, however, disfavor such radical departures from the traditional view not only for comparative but also for descriptive purposes (Mithun 1999:56-67).

The literature on word classes is vast and continues to expand. Scholars keep producing descriptive studies for languages virtually or completely unknown until recently from all over the world, thereby adding to the documentation of the cross-linguistic variation found in this particular domain as well. There is consensus on some issues related to word classes: it is not useful to define them exclusively, or mainly, based on semantic criteria, and the evidence used to identify the types must be language-specific. Scholars have not reached a consensus, however, on some fundamental questions: Do all languages show word classes? Are word classes the same, or at least meaningfully comparable, across languages? Perhaps most vexingly: Are word classes the same kinds of notions across languages_-or, put differently, just what are word classes?

Like some early studies (notably, Bloomfield 1933 and Martinet 1960), most of present-day functional typology emphasizes the challenges faced by theories of word classes that are too close to the accepted classification; recent studies in this vein include Hengeveld (1992), Croft (2001), Hengeveld, Rijkhoff, and Siewierska (2004), Bach (2004), and Rijkhoff and van Lier (2013). Perhaps unsurprisingly, such studies vary widely regarding the solutions they propose. The traditional view basically works with a universal inventory of word classes and a language-specific instantiation thereof (Classical Latin, for example, did not have articles, while Ancient Greek did, and some languages apparently lack adpositions [DeLancey 2005]). Croft's (2001) counterproposal consists in postulating nouns, verbs, and adjectives as typological prototypes but not as language-specific categories. Haspelmath (2010) proposes to distinguish language-specific ("descriptive") parts of speech from cross-linguistic ("comparative") ones strictly and systematically and mentions that the relationship between the two can be varied. Most of Chomskyan linguistics, by contrast, questions the seriousness of the challenges adduced by functional typology and maintains that a theory of word classes close (at least in spirit, often also in letter) to the accepted classification is to be preferred to the alternative views. The most lucid comprehensive study in this tradition is probably Baker (2003).

3.2. Wordhood domains. Even though Sapir once claimed that "[n]o more convincing test could be desired than this, that the naïve Indian, quite unaccustomed to the concept of the written word, has nevertheless no serious difficulty in dictating a text to a linguistic student word by word" (1921:chap. 2), many present-day scholars see the accepted notion of 
"word" as more problematic than traditionally assumed. Some recent studies (most prominently, Dixon and Aikhenvald 2002) rekindled the interest in several of the empirical and theoretical issues involved by articulating one such current position very clearly: the conventions observable in the domain of orthography are at best very imperfectly suggestive and at worst simply useless for linguistic analysis. By contrast, the domains of segmental and suprasegmental phonology on the one hand and morphosyntax on the other can help formulate useful units-even though these two kinds of units need not coincide. One can employ traditional phonological criteria (relating to segmental features, prosodic features, and phonological rules) to define a unit labeled phonological word (P-WORD) and familiar morphosyntactic ("grammatical") regularities (relating to a couple of paradigmatic, and to many syntagmatic, properties of the elements involved) to define a unit labeled grammatical word (G-WORD). Instead of concentrating on putatively default cases where p-words and g-words match (a thorough survey of such regularities is yet to be conducted, even for western European languages), scholars can scrutinize mismatches between these two. ${ }^{24}$

One noteworthy instance of such mismatches is related to the difference between two brands of nominal incorporation. In one kind of construction, the resulting g-word consists of one p-word. In the other, the resulting g-word consists of more than one p-word (note Mithun's 1984 "incorporation by juxtaposition" in Mayan, as well as Gerdts and Hukari's 2008 "noun stripping" in Salishan and Massam's 2009 "pseudo-incorporation" in Austronesian and in general). The most famous instance of mismatches between units of both domains consists in cliticization: an autonomous g-word may be part of an autonomous p-word rather than a p-word in its own right. ${ }^{25}$ Nevertheless, the notion of "clitic" covers a wide array of related but distinct forms, targeting as it does morphemes that show some morphosyntactic, but only limited phonological, autonomy. The accepted view basically leads to a situation similar to that discussed in $\mathbf{2}$ above for roots and affixes: one unit type ("words") is seen as fully autonomous (at least within phrases, sometimes within clauses), while its mirror image ("affix") is seen as fully non-autonomous, with a residual type in between, which has occasionally been explored in its own right in

24 Dixon (2002) addresses some such mismatches in Jarawara (Arawá; Brazil). For example, reduplication with verbs may lead to two p-words corresponding to one g-word (e.g., kéte ketébe [INTENS run] 'run a lot'), and some auxiliary-based constructions consist of two g-words corresponding to one p-word (e.g., amó na [sleep Aux:F] 'she sleeps'). (Four articles in Dixon and Aikhenvald 2002 deal with p- and g-wordhood in indigenous languages of the Americas.)

25 I have described some of such mismatches for Mapudungun, where two g-words can constitute a single p-word (in the familiar context of cliticization) and two p-words can constitute a single g-word (in some cases of complex verb stem formation, as well as with a less commonly recognized phenomenon called anti-cliticization) (Zúñiga 2014a). 
descriptive studies but seldom in comparative work. ${ }^{26}$ Since morphosyntactic and phonological autonomy are each best seen as multi-parametrical and scalar (e.g., Dixon and Aikhenvald 2002 and Haspelmath 2011), the notions of p-word, g-word, and clitic are in need of careful handling and qualification in order to be meaningfully operationalized, even on a language-specific basis. (See Van Gijn and Zúñiga 2014 for a partial argumentation of this point based on data from South American languages and Bickel and Zúñiga, forthcoming for a concrete proposal of how to proceed in Mapudungun and a Tibeto-Burman language.)

Some recent studies have argued that there might be two further significant problems here. First, it may be the case that p-words cannot be adequately defined in every single language; more precisely, there appear to be languages like Limbu (ISO-code: lif) (Tibeto-Burman; Nepal), where more than one p-word-like unit can be defined, and those like Vietnamese, where there is arguably none (Schiering, Bickel, and Hildebrandt 2010). Second, it may be the case that g-words are determinable on a language-specific basis but not cross-linguistically, rendering traditional morphological typology (as well as the traditional morphology-syntax divide) moot (Haspelmath 2011). ${ }^{27}$

If such criticism is to be taken seriously, there is much work still to be done in order to turn old intuitions about words into analytical notions that allow for meaningful cross-linguistic comparison-which is a prerequisite for meaningful cross-linguistic generalizations. To the best of my knowledge, no close parallels to the p-word-related problems of Limbu or Vietnamese have been explicitly reported for the Americas, but my own (admittedly preliminary) work on Mapudungun suggests that the Limbu situation (i.e., several p-wordlike units [Bickel and Zúñiga, forthcoming]) might be more easily found than hitherto assumed. Even though I have not yet seen Haspelmath's concerns subjected to close scrutiny, either in the typological or in the Americanist

${ }^{26} \mathrm{I}$ am grateful to an anonymous reviewer for drawing my attention to several such languagespecific studies: Crowel (1949) on Kiowa, Czaykowska-Higgins (1998) on Moses-Columbia Salish, Beck (1999) on Lushootseed, and Dyck (2009) on Cayuga. Russell (1999) is among the few studies with a cross-linguistic scope, and Aikhenvald (2002) deals with Tariana but explicitly proposes a comparative approach.

${ }^{27}$ Morphological typology has much more fundamental problems to solve than the disagreement about how best to define polysynthesis. Older work favored quantitative definitions ("how many morphemes per word" [see Sapir 1921 and Greenberg 1960]), while more recent work favors qualitative criteria ("what kinds of morphemes appear on predicative words" [see Evans and Sasse 2002 and Fortescue 2007]; (pro-)nominal incorporation takes center stage in Baker 1988; lexical affixation is criterial in Mattissen 2003) and even mixed criteria (e.g., Bickel and Nichols 2007). Nevertheless, since all definitions of polysynthesis proposed hitherto require some cross-linguistically viable definition of morphemes and g-words, if the latter are at best strictly language-specific, then polysynthesis is closer to a suggestive impressionistic notion than to a technically useful type (see Zúñiga $2014 b$ for more on this argument). 
literature, I think they pose a serious challenge to our accepted way of thinking about words.

3.3. Word typologies reconsidered. According to Boas, higher-level units, rather than words, might well be the relevant units to be used when studying human language- something arguably suggested by data from several indigenous languages of the Americas known to him a century ago. Present-day linguistics usually expresses some discomfort regarding definitions and uses of the notion "sentence," but the notion of "clause" is almost universally accepted and widely used (albeit not necessarily defined in the same way in all theoretical traditions). Discomfort regarding the different kinds of words that need to be postulated for analysis has not abated since Boas's time (at least not for everybody). By and large, however, serious misgivings about the very notion of word are a more recent development. ${ }^{28}$ Could we perhaps work with the generally accepted notions (i.e., clause and morpheme) alone? Put differently, which language-specific and/or cross-linguistic generalizations do we really need words and word classes for, exactly, and would the other notions-possibly complemented by new intermediate-level units-not perform just as well or even better?

A radically anti-traditional answer has potentially significant consequences for most typological issues addressed so far: without a cross-linguistically valid (g-)word, we do not seem to have cross-linguistically valid (g-)word classes, ${ }^{29}$ nor can we continue talking about compounds and nominal incorporation in the way we have done. Moreover, some issues that scholars have found relevant cannot be phrased in the usual terms anymore and need to be recast.

The processes of Mapudungun and Blackfoot sketched in $\mathbf{2}$ above, which appear to be prominent in many indigenous languages of the Americas, consist of simple verbs losing autonomy as they become parts of complex verbs and of a noun losing autonomy vis-à-vis a verb, respectively. This noun then possibly passes through intermediate stages, in which only compounds, or nominal stems, or nominal roots are licensed in the construction, and perhaps undergoing phonetic erosion and semantic bleaching. The erstwhile nominal root may eventually become an affix-in other words, (part of) a word may become part of another. Particularly noteworthy aspects of this

${ }^{28}$ An anonymous reviewer pertinently mentions that some early authors had reservations about the notion of word (e.g., Wundt 1900).

${ }^{29}$ Haspelmath (2010) does propose cross-linguistic "parts of speech," but I have some doubts about how well these would actually work. Crucial comparative concepts in his definitions are "adjectives," "nouns," "verbs," etc., but adjectives are defined by resorting to nouns (they may "narrow the reference of a noun"), and verbs are "defined in a manner analogous to the definition of 'adjective"" (2010:671). Moreover, Haspelmath dodges the comparative concept he deems potentially untenable ("word," addressed in detail in Haspelmath 2011) by resorting to another that he does not treat in detail ("lexeme"). Both this particular brand of circularity and the notion "lexeme" seem problematic to me within his line of reasoning. 
process include the synchronic variation observed and the insights one may gain into diachronic issues, which are in turn potentially illuminating for the exploration of areal and genealogical entanglements. With respect to synchronic variation, such affixes may be formally eroded but semantically very much intact, may be quite numerous, and their formal relationship to the still autonomous counterparts may become obscured by phonetic erosion and/or vocabulary renewal. With respect to diachronic issues, see Fortescue's (2013) notion of "old polysynthesis," arguably detectable in Wakashan, Athabaskan, and even Eskimo-Aleutian, compared to the "new polysynthesis" observable in Chukotko-Kamchatkan. Language-specifically, we are entitled (and even encouraged) to use somewhat different definitions of the terms; we can write about Mapudungun Verbs ("verbs") and Verbs 2 ("adjectives") and Blackfoot Verbs, for instance. Cross-linguistically, however, if some of our current terminological-analytic tools are less than useful ("root," "affix"), while others are very problematic ("noun," "verb," "word"), the sketch above has to be reformulated with a refined vocabulary that we have barely started developing. We certainly want to evaluate claims regarding old and new morphological developments in different families and areas. We apparently need to be much more careful terminologically, which in this case does mean analytically.

It goes without saying that I cannot possibly answer this complex and far-reaching question properly here, nor can I formulate and argue for an alternative theory of morpheme types, unit types (word classes), and unit domains in detail. Rather, I would simply like to suggest that twenty-firstcentury linguistics in general, and Americanist studies in particular, are still very much confronted with the Boasian questions.

4. Concluding remarks. Boas suggested that we might arrive at better views of genealogical relationships in the Americas once we knew more about the morphological structures of individual languages. He saw our knowledge as incomplete 100 years ago, particularly concerning an issue he deemed significant, namely, different kinds of compounding apparently leading to different kinds of derivational morphology, with both a recognizable family resemblance and a clear areal character. Nowadays, we see several areas of syntax as potentially volatile in contact scenarios-at least more volatile than some areas of morphology, which are more resistant to borrowing. Inflectional material is thought to be less easily borrowed than derivational elements (although there are convincing cases of purely functional, i.e., not material-dependent, convergence), and morphological processes similar to those discussed in this article are still assumed to be related to the rather conservative traits of grammatical structure. Nevertheless, there is much work to be done before we can address Boas's questions in both a modern and a satisfactory fashion. 
It would indeed be remarkable if we were able to show whether West Greenlandic, Yucatec Maya, and Pirahã "bear to [each other] a stronger affinity, вотн IN THE ROOTS OF VERBS AND THE FORMS OF GRAMMAR, than could possibly have been produced by accident" (Jones 1799:26 [my emphasis]). If "no philologer could examine them all three, without believing them to have sprung from some common source, which, perhaps, no longer exists," we would vindicate the intuition of DuPonceau, Whitney, and other late nineteenth-century observers (Joseph 2002:chap. 2) and keep working on the details of how such "affinity" became so obscured. If not, we would keep reconstructing protounits of moderate scope and working on possible prehistoric migrations and contact. Mass-comparison-based cognate sets did not do the job, however, nor did studies of polysynthesis. We need to know more about the roots of verbs and the forms of grammar, and understand their development paths better.

The roots of verbs look reasonably solid within well-established families (with notable exceptions like Blackfoot, where a non-negligible part of the root inventory is of unknown origin), but both their material and the way they work become rather difficult to compare across families. Something similar happens to the forms of grammar; inflectional and derivational material shows reasonable degrees of affinity within many families (albeit perhaps less so in lesser-studied families, especially in Central and South America) but become rather opaque cross-linguistically, at least for purposes of reconstruction. It is in order to note that, at present, even the possible affinity between Kutenai, Salishan, and Algonquian seems rather modest, for various reasons. First, we still know little about prehistoric contact. Second, many language descriptions are fragmentary and occasionally differ markedly in terminology and analysis from each other, even for closely related languages, thus delaying the recognition of affinities - this is often due to a misinterpretation of what it means to describe a language "in its own terms." Third, the roots of verbs and parts of grammar can, and apparently often do, develop in ways that make them difficult to track. One of the reasons for this difficulty is, in turn, the fact that our analytical toolkit is biased toward handling limited abstract polar extremes which, in the case of some American indigenous grammars, is probably not the most useful way to study morphological elements. Boas suggested as much a century ago, and numerous scholars have echoed the point more recently. It is definitely the time to develop better tools. We may well need to go beyond Jones's diagnostics ("the roots of verbs and the forms of grammar") to substantiate American indigenous long-distance relationships, but I would like to claim that we can still do a much better job handling those very diagnostics.

Practitioners and theoreticians have had ample time to develop tools and refine techniques since Boas's brief introductory paper-but so much has happened in Western linguistics since 1917. Leaving aside the important amount of descriptive work undertaken, we know that the first half of the 
twentieth century witnessed the rise and development of European and (North) American structuralism, and the second half saw the rise and development of Chomskyan linguistics. The Boasian tradition is characterized by an emphasis on the interdependency of language and its historical, social, and cultural contexts. Another hallmark is its method: fieldwork is seen as fundamental for ascertaining variation and universals in language(s). Even though the relativism-universalism debate is usually portrayed in stylized and inexact terms, it is quite clear that functional typology has been often biased toward the relativist view, an unmistakably Boasian legacy, just as Chomskyan linguistics has been always biased toward universalism.

There can be no doubt that it is healthy for any academic discipline to have different schools of thought, and this is certainly true when it comes to how linguistics addresses the issues raised by Boas (1917). Even though many scholars who prefer a deductive approach to defining word classes remain unpersuaded that the Boasian caveats really call for a radical rethinking of word class models, the discussion with and among induction-based practitioners does lead the discussion, however slowly, to more cogent arguments (see Polinsky 2012 for a recent example of such an exchange). The potential problems with the hitherto indispensable and central concept of "word" have not been widely discussed yet, but I am convinced that it is in the best interest of all kinds of linguists to address the issues raised and to develop a more principled, more useful, and widely accepted analytical toolkit for the study of morphology of natural languages, and I suspect that I am not alone.

So it is up to the heirs of the Boasian tradition, whatever theoretical persuasion they may espouse, to make serious progress in refining Boas's questions and answering them. Given the rates of change of our way of life in the past century and the nature of current challenges to the development of human societies, including the development of academia, the humanities, and linguistics, I will avoid making a forecast for such a time span. For the next 25 years, however, I would claim that linguistics will learn even more about all kinds of morphemes in indigenous languages of the Americas-perhaps even more than the profession has learned in the past 100 years-and that knowledge will not lead to jettisoning Boas's suggestions. Rather, it is likely to lead us to an improved understanding of how human languages, in the Americas and beyond, work.

\section{REFERENCES}

Adelaar, Willem. 2004. The Languages of the Andes. With Pieter C. Muysken. Cambridge: Cambridge University Press.

Aikhenvald, Alexandra. 2002. Typological parameters for the study of clitics, with special reference to Tariana. Word: A Cross-Linguistic Typology, ed. R. M. W. Dixon and Alexandra Aikhenvald, pp. 42-78. Cambridge: Cambridge University Press. 
Allen, Barbara J.; Donna B. Gardiner; and Donald G. Frantz. 1984. Noun incorporation in Southern Tiwa. IJAL 50:292-311.

Armoskaite, Solveiga. 2011. The destiny of roots in Blackfoot and Lithuanian. Ph.D. dissertation, University of British Columbia.

Augusta, FÉLix José DE. 1916. Diccionario araucano-español español-araucano. Santiago: Imprenta Universitaria.

B ACH, EMmON. 2004. Linguistic universals and particulars. Linguistics Today-Facing a Greater Challenge, ed. Piet van Sterkenburg, pp. 47-60. Amsterdam: John Benjamins.

BAKer, Mark. 1988. Incorporation: A Theory of Grammatical Function Changing. Chicago: University of Chicago Press.

2003. Lexical Categories: Verbs, Nouns, and Adjectives. Cambridge: Cambridge University Press.

Baker, Mark; Roberto Aranovich; and Lucía Golluscio. 2005. Two types of syntactic noun incorporation: Noun incorporation in Mapudungun and its typological implications. Language 81:138-76.

BaUer, LAurie. 1988. Introducing Linguistic Morphology. Edinburgh: Edinburgh University Press.

BECK, DAVID. 1999. Words and prosodic phrasing in Lushootseed narrative. Studies on the Phonological Word, ed. Tracy A. Hall and Ursula Kleinhenz, pp. 23-46. Amsterdam: John Benjamins.

2013. Unidirectional flexibility and the noun-verb distinction in Lushootseed. Flexible Word Classes: A Typological Study of Underspecified Parts-of-Speech, ed. Jan Rijkhoff and Eva van Lier, pp. 185-220. Oxford: Oxford University Press.

Bergenholtz, Henning. 1997. Nordisk Lleksikografisk ordbok. Tøyen, Norway: Universitetsforlaget.

Bickel, Balthasar, and Johanna Nichols. 2007. Inflectional morphology. Language Typology and Syntactic Description, vol. 3, Grammatical Categories and the Lexicon, 2nd ed., ed. Timothy Shopen, pp. 169-240. Cambridge: Cambridge University Press.

Bickel, Balthasar, and Fernando Zúñiga. Forthcoming. The word in polysynthetic languages: Phonological and morphological challenges. The Oxford Handbook of Polysynthesis, ed. Michael Fortescue, Marianne Mithun, and Nicholas Evans. Oxford: Oxford University Press.

BisAng, WALTER. 2009. Serial verb constructions. Language and Linguistics Compass 3:792-814.

Bloomfield, Leonard. 1933. Language. New York: Holt, Rinehart \& Winston. . 1946. Algonquian. Linguistic Structures of Native America, ed. Harry Hoijer, pp. 85-129. New York: Viking Fund.

BoAs, Franz. 1917. Introductory. IJAL 1:1-8.

Croft, William. 2001. Radical Construction Grammar: Syntactic Theory in Typological Perspective. Oxford: Oxford University Press.

Crowel, Edith E. 1949. A preliminary report on Kiowa structure. IJAL 15:163-67.

Czaykowska-Higgins, Ewa. 1998. The morphological and phonological constituent structure of words in Moses-Columbia Salish (Nxa?amcín). Salish Languages and Linguistics: Theoretical and Descriptive Perspectives, ed. Ewa Czaykowska-Higgins and M. Dale Kinkade, pp. 153-95. Berlin: Mouton de Gruyter.

Davis, Philip, And Ross Saunders. 1984. Propositional organization: The $s$ - and $s i$ - prefixes in Bella Coola. IJAL 50:208-31.

Déchaine, Rose-Marie, and Natalie Weber. 2015. Head-Merge, Adjunct-Merge, and the syntax of root categorisation. Simon Fraser University Working Papers in Linguistics 5:38-47.

DeLancey, Scott. 1996. The bipartite stem belt: Disentangling areal and genetic correspondences. Proceedings of the Twenty-Second Annual Meeting of the Berkeley Linguistics Society, pp. 37-54. Berkeley: University of California.

. 1999. Lexical prefixes and the bipartite stem construction in Klamath. IJAL 65:56-83. 
2000. Argument structure of Klamath bipartite stems. Proceedings of the Twenty-Sixth Annual Meeting of the Berkeley Linguistics Society, pp. 15-25. Berkeley: University of California.

2005. Adpositions as a non-universal category. Linguistic Diversity and Language Theories, ed. Zygmunt Frajzyngier, Adam Hodges, and David Rood, pp. 185-202. Amsterdam: John Benjamins.

Dixon, R. M. W. 2002. The eclectic morphology of Jarawara, and the status of word. Word: A Cross-Linguistic Typology, ed. R. M. W. Dixon and Alexandra Aikhenvald, pp. 125-52. Cambridge: Cambridge University Press.

2014. Making New Words: Morphological Derivation in English. Oxford: Oxford University Press.

Dixon, R. M. W., And Alexandra Aikhenvald. 2002. Word: A typological framework. Word: A Cross-Linguistic Typology, ed. R. M. W. Dixon and Alexandra Aikhenvald, pp. 1-41. Cambridge: Cambridge University Press.

DYCK, CARrIE. 2009. Defining the word in Cayuga (Iroquoian). IJAL 75:571-605.

Evans, Nicholas, And Hans-Jürgen SAsSe. 2002. Introduction: Problems of polysynthesis. Problems of Polysynthesis, ed. Nicholas Evans and Hans-Jürgen Sasse, pp. 1-14. Berlin: Akademie Verlag.

Fortescue, Michael. 1980. Affix ordering in West Greenlandic derivational processes. IJAL 46:259-78.

2007. The typological position and theoretical status of polysynthesis. Tidsskrift for Sprogforskning 5, Article 2:1-27.

2013. Polysynthesis in the Arctic/Sub-Arctic. How recent is it? Language Typology and Historical Contingency, ed. Balthasar Bickel, Lenore A. Grenoble, David A. Peterson, and Alan Timberlake, pp. 241-64. Amsterdam: John Benjamins.

Frantz, Donald G. 2009. Blackfoot Grammar. 2nd ed. Toronto: University of Toronto Press.

Frantz, Donald G., and Norma J. Russell. 1995. Blackfoot Dictionary of Stems, Roots, and Affixes. 2nd ed. Toronto: University of Toronto Press.

GeneE, Inge. 2013. On the representation of roots, stems and finals in Blackfoot. Casebook in Functional Discourse Grammar, ed. J. Lachlan Mackenzie and Hella Olbertz, pp. 95-123. Amsterdam: John Benjamins.

GERDTs, Donna B. 1998. Incorporation. The Handbook of Morphology, ed. Andrew Spencer and Arnold M. Zwicky, pp. 84-100. Oxford: Blackwell.

2003. The morphosyntax of Halkomelem lexical suffixes. IJAL 59:345-56.

Gerdts, Donna B., And Thomas Hukari. 2008. Halkomelem denominal verb constructions. IJAL 74:489-510.

Gleason, H. Allan, JR. 1955. Introduction to Descriptive Linguistics. New York: Holt, Rinehart \& Winston.

GodDARD, IvEs. 1990. Primary and secondary stem derivation in Algonquian. IJAL 56:449-83.

GreENBERG, JosePh. 1960. A quantitative approach to the morphological typology of language. IJAL 26:178-94.

HARMElink, Bryan. 1992. La incorporación nominal en el mapudungun. Lenguas Modernas 19:129-37.

Haspelmath, Martin. 2010. Comparative concepts and descriptive categories in crosslinguistic studies. Language 86:663-87.

2011. The indeterminacy of word segmentation and the nature of morphology and syntax. Folia Linguistica 45:31-80.

Hengeveld, Kees. 1992. Non-Verbal Predication: Theory, Typology, Diachrony. Berlin: Mouton de Gruyter.

Hengeveld, Kees; Jan Rijkhoff; and Anna Siewierska. 2004. Parts-of-speech systems and word order. Journal of Linguistics 40:527-70.

Hoijer, Harry. 1931/1933. Tonkawa: An Indian language of Texas. Extract from Handbook of American Indian Languages, vol. 3, pp. 1-148. New York: Columbia University. 
JaCobsen, William. 1980. Washo bipartite stems. American Indian and Indoeuropean Studies: Papers in Honor of Madison S. Beeler, ed. Kathryn Klar, Margaret Langdon, and Shirley Silver, pp. 85-99. Berlin: Mouton de Gruyter.

Jones, Sir William. 1799. The Works of Sir William Jones. Vol. 1. London: G. C. \& J. Robinson and R. H. Evans, successor to Mr. Edwards.

JosepH, JoHn. 2002. From Whitney to Chomsky: Essays in the History of American Linguistics. Amsterdam: John Benjamins,

KIBRIK, ANDREJ A. 2005. On the use of "quasi-grammeme" in Athabaskan. East West Encounter: Second International Conference on Meaning $\leftrightarrow$ Text Theory, ed. Juri D. Apresjan and Leonid Iomdin, pp. 208-18. Moscow: Slavic Culture Languages Publishing House.

Levy, Paulette. 1999. From 'part' to 'shape': Incorporation in Totonac and the issue of classification by verbs. IJAL 65:127-75.

MARTinet, ANDRÉ. 1960. Elements of a functional syntax. Word 16:1-10.

Massam, DiANE. 2009. Noun incorporation: Essentials and extensions. Language and Linguistics Compass 3/4:1076-96.

Mattissen, Johanna. 2003. Dependent-Head Synthesis in Nivkh: A Contribution to a Typology of Polysynthesis. Amsterdam: John Benjamins.

Mel'čuk, IgoR A. 1993. Cours de morphologie générale. Montréal: Les Presses de L'Université de Montréal.

MerLan, Francesca. 1976. Noun incorporation and discourse reference in Modern Nahuatl. IJAL 42:177-91.

Mithun, Marianne. 1984. The evolution of noun incorporation. Language 60:847-94.

1997. Lexical affixes and morphological typology. Essays on Language Function and Language Type, ed. Joan Bybee, John Haiman, and Sandra Thompson, pp. 357-71. Amsterdam: John Benjamins.

. 1999. The Languages of Native North America. Cambridge: Cambridge University Press.

. 2000. Noun and verb in Iroquoian languages: Multicategorisation from multiple criteria. Approaches to the Typology of Word Classes, ed. Petra M. Vogel and Bernard Comrie, pp. 397-420. Berlin: Mouton de Gruyter.

Moesbach, Ernesto Wilhelm de. 1962. Idioma mapuche. Padre las Casas: Imprenta San Francisco.

Polinsky, Maria, ed. 2012. Special issue of Theoretical Linguistics 38, nos.1/2.

Proulx, Paul. 1985. Proto-Algic II: Verbs. IJAL 51:59-94.

QueIXalós, Francesc. 2006. The primacy and fate of predicativity in Tupi-Guarani. Lexical Categories and Roots Classes in Amerindian Languages, ed. Ximena Lois and Valentina Vapnarsky, pp. 249-87. Bern: Peter Lang.

QuinN, Conor. 2009. Semantic packaging and the manner/means constraint on Algonquian verbal stem structure. Paper presented at the Annual Meeting of the Society for the Study of the Indigenous Languages of the Americas, San Francisco, January 8-11.

RHodes, RichARD. 2016. On the semantics of abstract finals: 35 years later. Papers of the Fortyfourth Algonquian Conference, ed. Monica Macaulay, Margaret Noodin, and J. Randolph Valentine, pp. 1-24. Albany: State University of New York Press.

Rice, Keren. 2000. Morpheme Order and Semantic Scope: Word Formation in the Athapaskan Verb. Cambridge: Cambridge University Press.

RijkHoff, JAN, AND Eva van Lier, eds. 2013. Flexible Word Classes: A Typological Study of Underspecified Parts-of-Speech. Oxford: Oxford University Press.

Russell, Kevin. 1999. The "word" in two polysynthetic languages. Studies on the Phonological Word, ed. Tracy A. Hall and Ursula Kleinhenz, pp. 203-21. Amsterdam: John Benjamins.

SAdock, JeRrold M. 2012. The Modular Architecture of Grammar. Cambridge: Cambridge University Press. 
SAlas, Adalberto. 2006. El mapuche o araucano: Fonología, gramática y antología de cuentos. Santiago: Centro de Estudios Públicos.

SAPIR, EDWARD. 1921. Language: An Introduction to the Study of Speech. New York: Harcourt, Brace \& Co.

SASSE, HAns-Jürgen. 1998. Der irokesische Sprachtyp. Zeitschrift für Sprachwissenschaft $7: 173-213$.

Schiering, René; Balthasar Bickel; and Kristine Hildebrandt. 2010. The prosodic word is not universal, but emergent. Journal of Linguistics 46:657-709.

SmeEts, Ineke. 2008. A Grammar of Mapuche. Berlin: Walter de Gruyter.

Sullivan, Paul R. 1984. Noun incorporation in Yucatec Maya. Anthropological Linguistics 26:138-60.

UCHIHARA, HiRoto. 2014. Cherokee noun incorporation revisited. IJAL 80:5-38.

Valentine, J. RANDOLPh. 2001. Nishnaabemwin Reference Grammar. Toronto: University of Toronto Press.

VAn Gijn, RiK, And Fernando ZúÑIGa. 2014. Word and the Americanist perspective. Morphology 24:135-60.

Velupillai, ViveKa. 2012. An Introduction to Linguistic Typology. Amsterdam: John Benjamins.

WoOdBuRY, Hanns. 1975. Onondaga noun incorporation: Some notes on the interdependence of syntax and semantics. IJAL 41:10-20.

WundT, WiLHelm. 1900. Die Sprache. 2 vols. Leipzig: Engelmann.

ZúNIIGA, Fernando. 2000. Mapudungun. Munich: Lincom Europa.

. 2001. Dos progresivos y dos resultativos en mapudungun. Línguas Indígenas Americanas 1:63-75.

2006. Mapudungun. El habla mapuche. Santiago de Chile: Centro de Estudios Públicos. 2014a. (Anti-)cliticization in Mapudungun. Morphology 24:161-75.

. 2014b. Polisíntesis y lenguas indoamericanas. III Encuentro de Lenguas Indígenas Americanas: Libro de Actas, ed. Marisa Malvestitti and Patricia Dreidemie, pp. 631-48. Viedma, Argentina: Universidad Nacional de Río Negro.

. Forthcoming. Mapudungun. The Oxford Handbook of Polysynthesis, ed. Michael Fortescue, Marianne Mithun, and Nicholas Evans. Oxford: Oxford University Press. 